\title{
New Records and Observations on Paleo-American Artifacts from Cerro Largo, Northeastern Uruguay and a Peculiar Case of Reclaimed Fishtail Points
}

\author{
Hugo G. Nami \\ CONICET-Igeba, Laboratory of Geophysics "Daniel A. Valencio”, Department of Geological Sciences, FCEN, UBA, \\ Ciudad Autónoma de Buenos Aires, Argentina \\ Email: hgnami@fulbrightmail.org
}

Received 9 June 2015; accepted 21 July 2015; published 24 July 2015

Copyright (C) 2015 by author and Scientific Research Publishing Inc.

This work is licensed under the Creative Commons Attribution International License (CC BY).

http://creativecommons.org/licenses/by/4.0/

(c) (i) Open Access

\begin{abstract}
A research program directed to deepening the knowledge and understanding of Paleo-American "fishtail" points is being carried out. In pursuit this goal, lithic remains from Cerro Largo department, northeastern Uruguay is examined. One of the samples comes from Paso Centurión, a surface site that has yielded the greatest number of fishtail points in Uruguay. There, and at the Paso Taborda site, several exemplars were reworked as scraping tools, constituting a peculiar case of stone tool recycling and reclaiming by post-Pleistocene hunter-gatherers. The examined collection shed new light on regional lithic assemblages, stone tool behavior and the early colonization of southeastern South America. Additionally, the study of other Uruguayan fishtails show the use of edge-to-edge and overshot flaking, technical features shared with Paleoindian fishtailed points from North and Central America. Similarities with other Paleoindian points from both hemispheres of the New World in relation to the SouthAmerican fishtail origins are discussed.
\end{abstract}

Keywords

Fishtail Points, Projectile Technology, Morphological Variation, South America, Uruguay

\section{Introduction}

In scientific research about humankind, the evolution, dispersion and colonization of the world is one of the most fascinating and intriguing anthropological and archaeological issues (Gamble, 1996; Akazawa and Szath-

How to cite this paper: Nami, H. G. (2015). New Records and Observations on Paleo-American Artifacts from Cerro Largo, Northeastern Uruguay and a Peculiar Case of Reclaimed Fishtail Points. Archaeological Discovery, 3, 114-127. 
mary, 1999, Liu et al., 2006). In this process, initiated in the terminal Miocene at about 5 million years ago, the Americas were the last colonized continents during the Late Pleistocene, in a time span subject to debate (Adovasio and Page, 2002, Meltzer, 2009). However, an indubitable fact is that during the last millennium of the Pleistocene at $\sim 11,000$ - 10,000 uncalibrated radiocarbon years B.P. $(\sim 11-10$ RCYBP hereafter) the New World was populated from Beringia to Tierra del Fuego (Graf et al., 2013; Nami, 2014a).

A primary evidence to assess Paleo-American problems is lithic remains. They provide diverse clues regarding the human dispersion in both hemispheres of the New World. To understand general and particular issues of Late Pleistocene human groups, stone tools, mainly projectile points from those times have been subjected to a broad range of investigations. They have been useful in examining the variability of patterns at different localities; and allow the observation of numerous issues concerning their reduction sequences, morphology and function (Rondeau, 2009; Bradley et al., 2010; Jennings, 2008; Shott, 2013; White, 2013; and many others). Beyond, strictly technological issues, projectile points are also useful to cope with topics related with studies on technological organization, mobility and social networks of diverse traditional societies (Wiessner, 1983, Amick, 1995, 1996, Nami et al., 2015).

Clovis, the oldest Paleoindian fluted point, had an extraordinary dispersion through North America. Similarly, in South America, the "fishtail", "Fell's cave", or just "Fell" projectile point is a wide-spread Paleo-American marker dated between 11 - 10 RCYBP (Nami, 2007: Table 1, Dillehay, 2011: Appendix one, Prates et al., 2013).

To discern colonization events and further New World socio-cultural developments, since the early 1980s we have performed a research program directed to deepening the knowledge and understanding of the morphological variation, technology and function of early stone tools. Particular focus was made on the fishtail points and other artifacts (Nami, 2007, 2010a, 2013; Nami and Castro, 2014). As part of these investigations, this paper reports new data obtained on Paleo-American lithic remains from Cerro Largo (CL) department, northeastern Uruguay (Figure 1).

\section{Archaeological Remarks}

Located in southeastern South America, Uruguay Republic is divided into 19 departments. Covering a surface area of $13,648 \mathrm{~km}^{2}$, Cerro Largo $\left(32^{\circ} 22^{\prime} 5 " \mathrm{~S}, 54^{\circ} 10^{\prime} 44^{\prime \prime} \mathrm{W}\right)$ is surrounded by fluvial courses acting as natural borders.

The archaeology of Cerro Largo (CL, hereafter) is mainly known from the Holocene mounds called Cerritos (Baeza et al., 1980, Cabrera Perez, 2005). They are distributed from south Brazil to northeastern Argentina (Bonomo, 2012, García, 2012). In eastern Uruguay they were extensively studied at Rocha department (Iriarte et al., 2004; Iriarte, 2006).
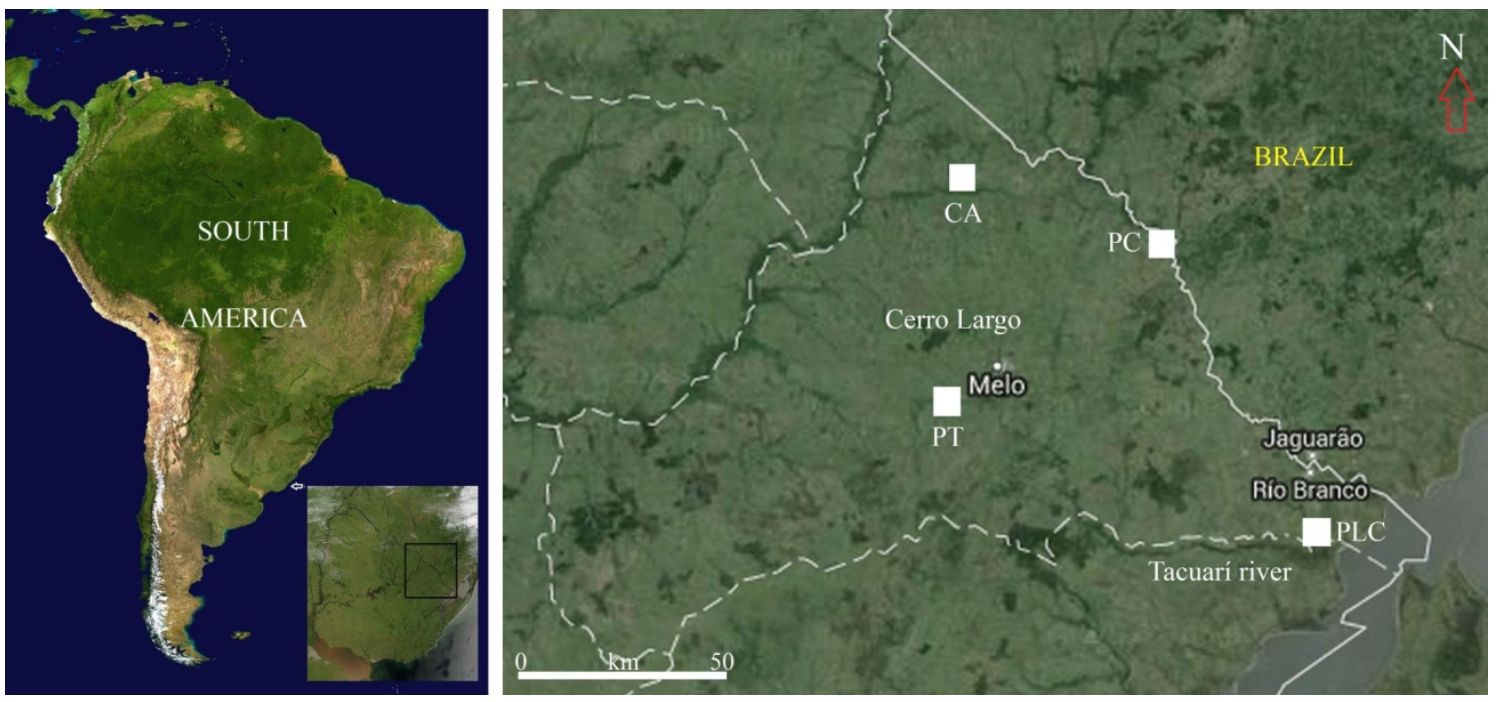

Figure 1. Map of South America and the location of Cañada de Aceguá (CA), Paso Centurión (PC), Paso Taborda (PT), and Paso La Catumbera (PLC) locales in the Cerro Largo department showed with a square in the map of Uruguay (after Google Maps, 2014). 
During the last years the Uruguayan Paleo American record have been of increasing interest for many authors (Suárez, 2009, Castiñeira et al., 2011, López Mazz, 2013, Meneghin, 2015). Their research is made with remains from buried and surface records. Significant evidence of Paleo-American vestiges has been witnessed by the fishtail points finds. In this regard, the Uruguayan territory has one of the highest densities in South America. Except a few pieces, most of them are surface discoveries which are curated in public and private collections. Resulting from different causes, collectors with different attitudes are a widespread phenomenon. The study of their collections must be carefully made, especially with concerns about the specimens' origin and authenticity (Chase et al., 1988, Femenías et al., 2011). Being aware of this issue, from a technological perspective, artifacts from different kind of collections are useful for discussing diverse archaeological topics (e.g. Castiñeira et al., 2011; López Mazz, 2013). Thus, good will between private collectors and professional archaeologists allows understanding and depth of study on diverse aspects of regional lithic technology (Nami, 2013). Continuing this research across Uruguay, I examined a significant Paleo-American sample $(\mathrm{n}=21)$ from the collections of Mr. J. Rendo (Montevideo city) and the Museo Histórico Regional de Cerro Largo (MHRCL), Melo city.

The only previously reported Paleoindian find from CL was the fishtail point found by Mr. C. Etcheverry in Cañada de Aceguá (CA, Figure 2(a)), a small creek situated in the border with Brazil (Schobinger, 1974: figure 3; Bosch et al., 1980: figure 17). The new artifacts reported here come from known and unknown sites and/or localities. They are as follows:

Paso Taborda (PT) is located on the main course of Bañados de Medina creek, at $15 \mathrm{~km}$ SE of Melo city (Figure 1). There, when the water level was down, archaeological and paleontological finds occured on a clay surface. A large number of artifacts, mainly projectile points come from this site, among them, three Fell pieces.

Paso Centurión (PC) is a sandy area on the Yaguarón River at $52 \mathrm{~km}$ north of Melo on the Brazilian border (Figure 1). Except the exemplar illustrated in Figure 3(a), formerly in the Mr. C. Echeverry collection, the remaining ones were collected by Mr. Ramón Bazz, who made a collection of artifacts found in the surface during the first half of the past century. By their quality, it seems that he was highly selective with the gathered objects. Most of them are entire projectile points and other outstandingly specimens. Remarkable is the significant number of fishtail heads $(n=16)$.

Tacuarí river (TR) is placed in the south of CL. The only Fell point found there come from Paso La Catumbera (Figure 1).

The provenience of the remains curated at the MHRCL is unknown. However, they add three pieces to the Uruguayan Paleoindian record. (Nami, 2015), one of them, a Paleo-American point.

\section{Analysis, Observations and Results}

During the last years research advances allowed deeper understanding of the fishtail point's attributes and morphological variations (Nami, 2013, 2014a). Many specimens from PC belong to the lanceolate variety (e.g. Figures 3(b)-(d)) with narrow blades, stems with parallel concave or incurvate borders, and concave base with pointed basal corners or ears (sensu Turner and Hester, 1985; Nami, 2014a: figure 25 4b). Remarkably is their similarity with other fishtails observed in several Uruguayan places, such as El Puente, Cacique and Carpintería creeks (Nami, 2013: figure 3m, p, 4b, o). Similar pieces have been found in other Southamerican locales; for instance, Dos Amigos, Argentina (Flegenheimer et al., 2013: figure 21-6: 13) and Cueva del Medio (Nami, 2014a: figure 22i). One specimen from PC and the one curated at MHRCL have broad blades with convex borders, rounded shoulders and slightly contracted stems with concave borders (Figure 3(a)). Several lanceolate exemplars from PC display pointed basal corners (Figures 3(b)-(d), Figure 3(l) and Figure 3(m)), a feature also recognized in other Uruguayan Fell points such as the one from Paso de la Cruz and Laguna Negra at Durazno and Rocha departments respectively (Figure 4(b) and Figure 4(c)). A notable preform of this sort of variety with a clear basal beveled platform for fluting is exhibit in Figure 4(a). Remarkable is the similarity of the specimen exhibited in Figure 3(j) with those found at Cueva del Medio, Chile (Nami, 1987: Figure 16b; Nami and Heusser, 2015: Figure 3b). In most pieces the stems’ bases were shaped by short pressure retouch. The specimen showed in Figure 3(e) has long flutes on both faces. Its thickness is slightly thicker than many fishtail points; probably intentionally preformed for fluting by direct percussion flaking. After flute detachment the base was shaped by short pressure retouch. Southamerican fishtail points show diverse basal treatments (Nami, 2003, 2014a) and by comparison with other alternatives, fluting is present on only a small amount of pieces. Flutes were obtained on diverse materials, such as black volcanic rocks (Bird, 1969), quartzite 


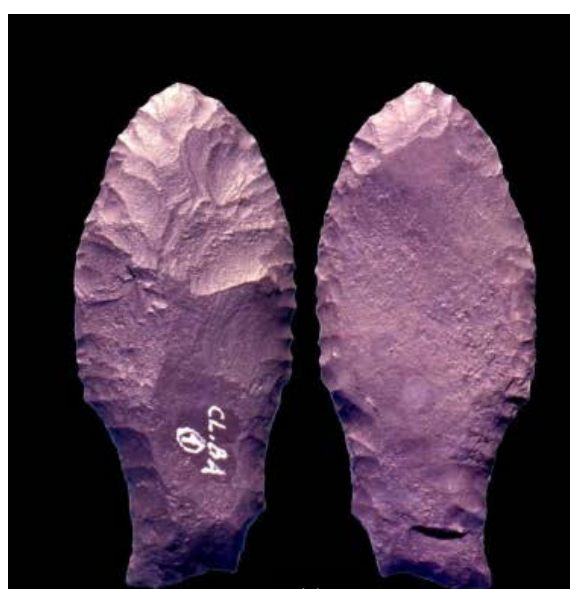

(a)

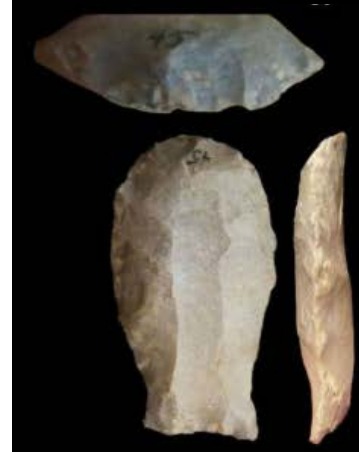

(c)

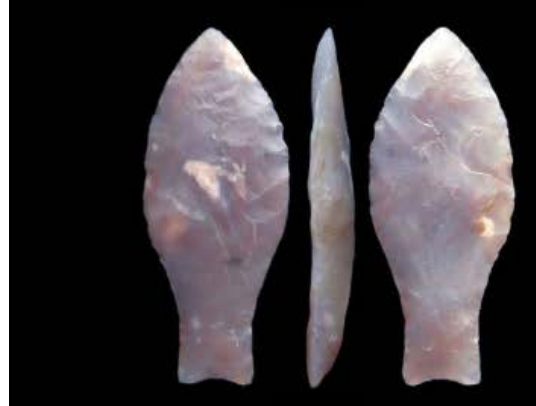

(e)

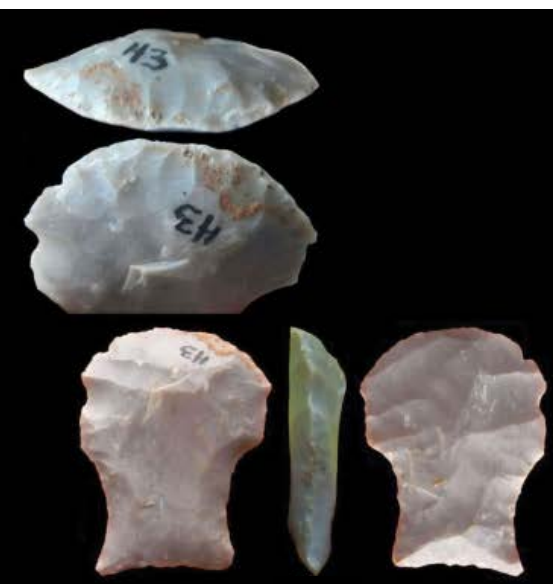

(b)

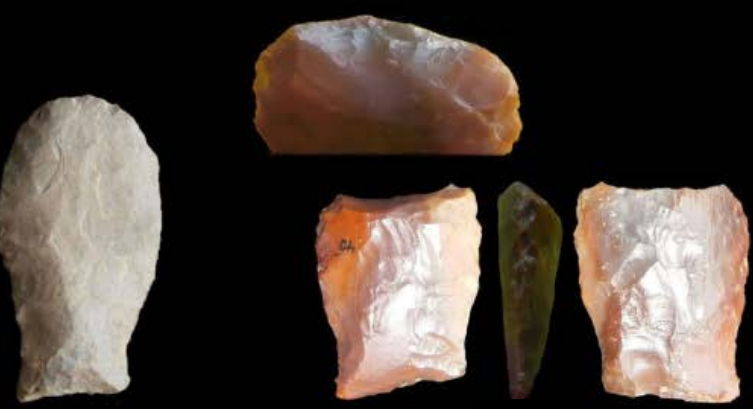

(d)
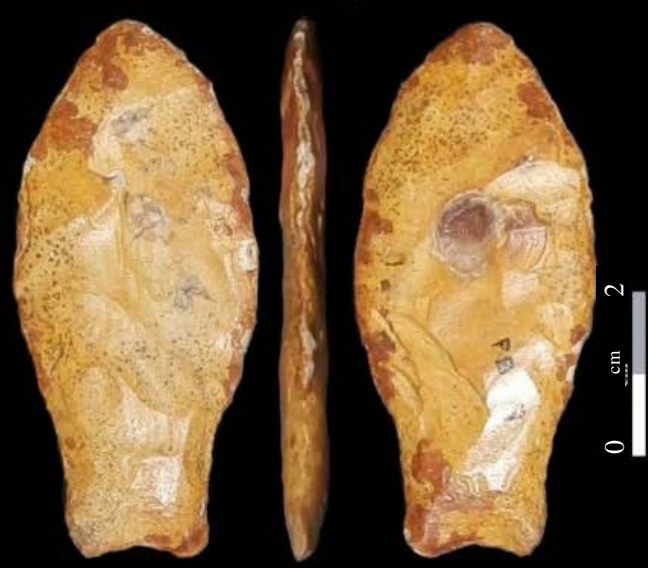

(f)

Figure 2. Fell points described in text and edge details of the reclaimed pieces as end-scrapers. (a) CA; (b)-(d) PT; (e) TR; (f) Unknown origin.

(Nami, 2010a: figure 2 1l), and quartz (Briceño Rosario, 1999: figure 17; Nami, 2010a: figure I f) but most on optimal rocks, such as obsidian (Mayer-Oakes, 1986: figure 37-38; Nami, 1992, 2010a: figure I h-i; 2014b: figure 16-18, 25), and flint-like material (Díaz Rodríguez, 2008: figure 2; Nami, 2010a: figure I a-d; 2013: figure 3l, q, Flegenheimer et al., 2013: figure 21.6: 12, Loponte et al., 2015: figure 2, 5).

According to longitudinal cross-sections observed in Figure 2, Figure 3, the thicker part of each piece is randomly located in different places. Maximum thickness may be near the tip, the center, the blade/stem intersection, and/or the stem. This fact is also observed in other pieces throughout Latin America (e.g. Bosch et al., 1980; Nami, 2013). 


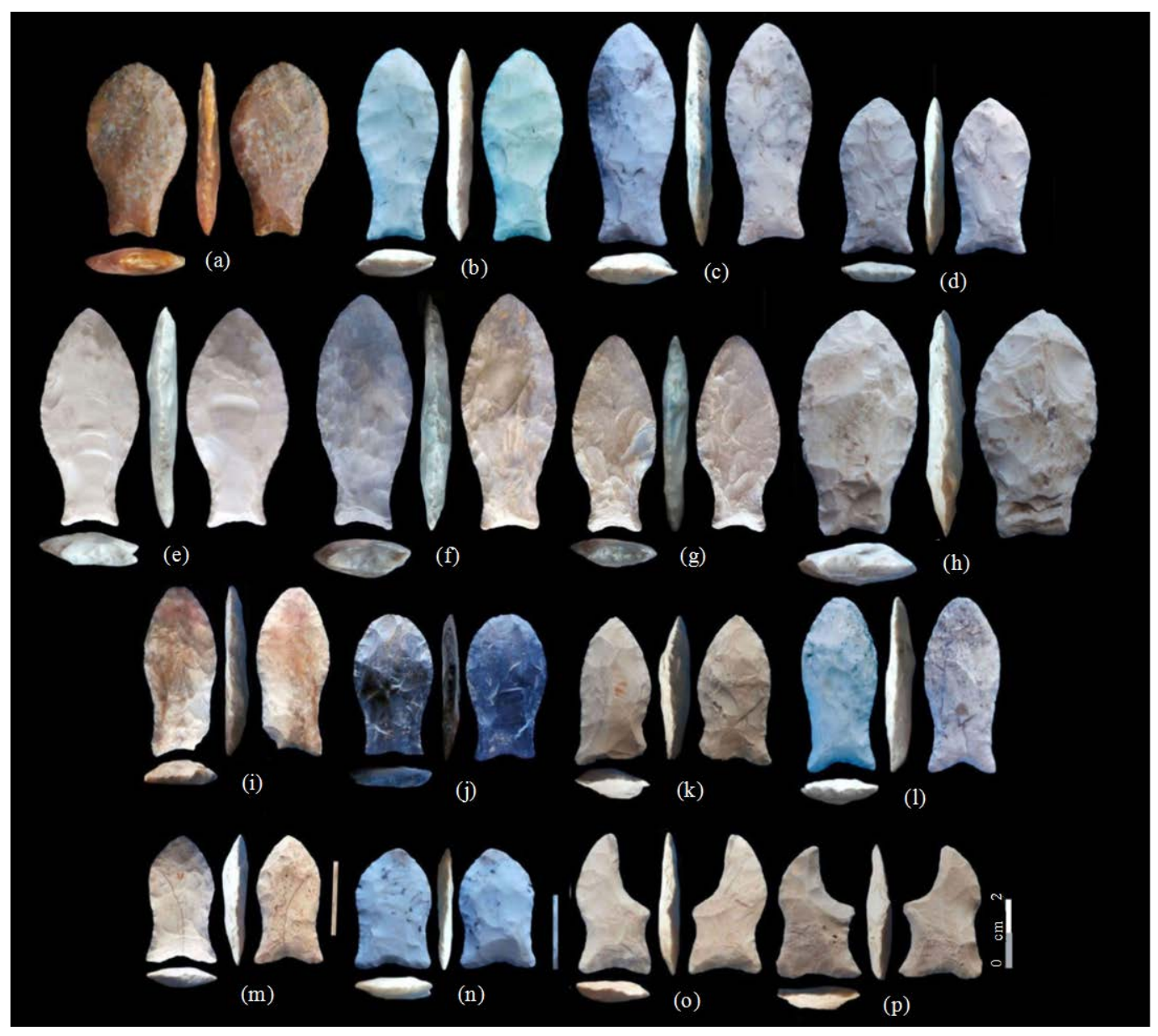

Figure 3. Fishtail points from PC (except when is clearly expressed in the acknowledgements section, all the photographs are by the author).

The examined fishtails were manufactured employing thin flake-blanks and thinned bifaces made from thicker blanks. The former are visible in pieces from CA (Figure 2(a)), PC (Figure 3(a)), PT (Figure 2(b)), and TR (Figure 2(e)). One of the clearest examples is the one from CA that shows remains of the flake's ventral face. Except in the distal part were retouches are deeper, it was mostly finished by short pressure retouch $\sim 4-5$ by $\sim 5$ $\mathrm{mm}$ wide and depth in both faces. Usually, for final shaping this kind of short and/or marginal retouch is bifacially applied with diverse continuity; hence the ventral face of the flake-blank is visible. Several pieces were made mostly by percussion (Figures 3(f)-(h)); and many finished by short pressure retouches at PC, and MHRCL (e.g. Figure 2(f), Figures 3(a)-(d), Figure 3(i)). This kind of production was a regular pattern among hunter-gatherers using these points. Pieces of similar manufacture were found in Ecuador (Mayer-Oakes, 1986, Nami, 2014b), Chile (Bird, 1969: figure 2a, 3f), Argentina (Martínez, 2001, Laguens et al., 2007, Patané Araoz and Nami, 2014), Brazil (da Silva Lopes and Nami, 2011, Loponte et al., 2015), and Uruguay (Nami, 2013: figure 3p, 4b, d). Also, longitudinal and transversal cross-sections are generally plano-convex due to the use of thin flakes. In PT and PC the flake-scars underlying the short pressure retouches that finished the points suggest the use of bifacial thinning from thicker blanks (Figures 3(f)-(h), Figure 4(d)-(g)) widely documented in several sites across South America (Nami, 2013, 2014b).

Once the finished product was used, they generally subjected to resharpening. In the case of hafted implements, resharpening is usually done while it is still in the handle (e.g. Holmes, 1919: figures 172, 174-175; Callahan, 1981: figures 17-18). In Fell points this is detectable when the blade form and symmetry is highly modified; retouch does not follow the remaining original pattern that finished the point, and/or the borders are strongly rounded or do not have enough mass to continue the task. According to the lack of mass in the blade that allows continued resharpening, it was catalogued as: 1 ) low or minimum: the blade was a little modified in 


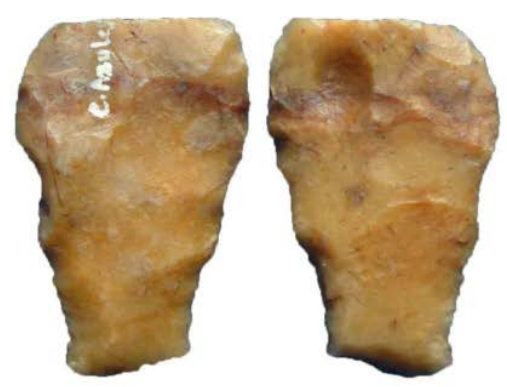

(a)

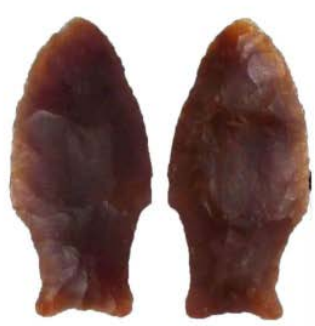

(d)

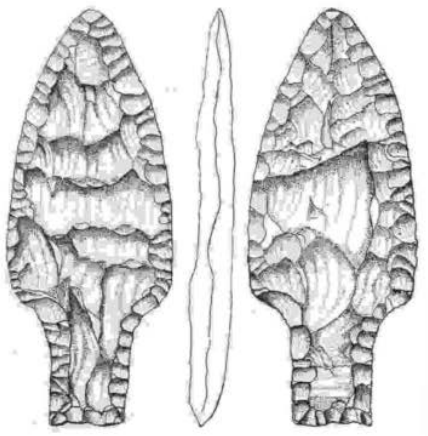

(f)

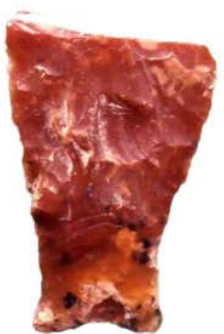

(b)

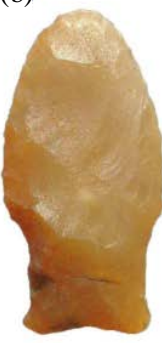

(e)

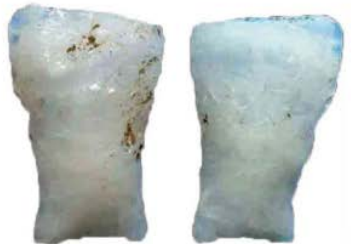

(c)

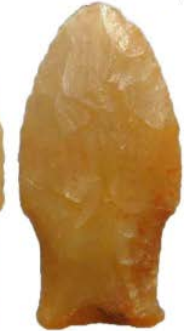

)

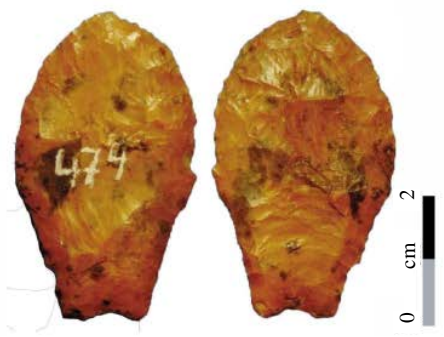

(g)

Figure 4. Fell points from different Uruguayan locales. (a)-(c) lanceolate variant. (a) Preform from Cerros Azules; (b) Paso de La Cruz; (c) Laguna Negra; (d)-(g) with edge-to-edge and/or overshot flake scars. (d) Baigorria dam; (e) Merin lagoon; (f) La Palomita; (g) Buena Vista hill.

its symmetry; 2) medium: despite some modification the blade has some mass to continue its useful life; finally, 3) intense, maximum or saturated: the blade does not have enough mass to bear continued reworking, hence, the piece is discarded (Nami, 2013). Having in mind Fell points with little or no resharpening (Figure 2a, 3a; Nami, 2013: figures 3g, r, 4k, l; 2014a: figures 19-20), specimens from PC show low (Figure 3(i)), medium (Figure 3(d), Figure 3(j)) and saturated resharpening (Figure 3(m) and Figure 3(n)), facts also observed in other Uruguayan and Southamerican examples (Nami, 2013: figures 3b, f, o, 4c; Nami, 2014b).

Recycle Fell points are common; however, they are just now being recognized as a part of the Paleo-American technological behavior (see Loponte et al., 2015 for a discussion about this topic). As a process to transform discarded materials, recycling is considered as re-edging the blade of a fishtail point to create a new artifact different with a different function from that for which it was manufactured. Recycling can be performed by the members of the socio-cultural system that produced it or, by others that acquired a point as an abandoned piece from an archaeological context; these are considered reclaimed artifacts (Schiffer, 1987, 99-ss). In this regard, two fishtails from PC show one beveled concave border (Figure 3(o) and Figure 3(p)). In South Brazil and Uruguay this is a fairly common feature of the stemmed Holocene points, called "sickles" or "foices" or "tipo hoz" (Baeza et al., 2001) and “drill” or "concave side-scraper” (Taddei, 1987: figures 21: 4-5, 24, 13). Also in PT there are three fishtails recycled as end-scrapers (Figures 2(b)-(d)), an unknown aspect of Paleo-American technological behavior.

Except few specimens recorded in the border of northern Patagonia in Argentina (Nami, 1984: 89, 7), in the 
southern cone of South America the re-use of projectile points as end-scrapers is a rare fact. However, in southern Brazil and Uruguay there are stemmed points recycled in this manner. Actually, PT yielded Holocene points recycled in the same way (Figure 5), a phenomenon existing in nearby sites. Taddei (1980: figure XII 25-26, 1987, 24: 4) illustrated points recycled as end-scraper and graver (sensu Turner and Hester, 1985) from Paso del Puerto, Uruguay. Cerrito Dalpiaz rockshelter (southeastern Brazil) yielded a stratigraphic record with stemmed projectile points. From the cultural-history perspective, in Cerrito Dalpiaz sequence, they characterize the "period II" dated at 6.0 - 4.2 RCYBP, attributed to the "Umbu tradition" (Dias, 2007, Bueno et al., 2013). Interestingly, "stemmed scrapers" which are obviously recycled points were reported from that context (Miller, 1969: figure 8 l-n, o') and other sites ascribed to the "Rio Pardinho phase" of the same archaeological construct (Schmitz, 1987: figure 19a-e). Hence, due to the compatibility with the recycling behavior observed in the aforementioned artifacts, it may be suggested that the scraping tools produced on fishtail heads were made by post-Pleistocene local hunter-gatherers who collected the points from archaeological sites during the early and middle Holocene. At the present, the evidence shows that South American foragers who employed fishtails did not practice this kind of recycling for making end-scrapers, although the use and/or re-use of Fell points in other functions might also have occurred during the last millennium of the Pleistocene. Actually, currently it is possible to propose that besides projectile tips, the morphology of some Fell points suggests their reuse as knives or lateral scraping tools. As shown in Figures 6(b)-(d), some Uruguayan specimens show a beveled border suggesting another form or resharpening; also there are pieces with asymmetrical blades with one straight or slightly convex border and/or convex ends insinuating a similar situation. Additionally, this fact was observed in other locales of South America, such as the Ilaló region, Ecuador (Figure 6(a)); Cerro El Sombrero, Argentina (Flegenheimer et al., 2009); Fell's cave (Figure 6(e)), and Magallanes province (Figure 6(f)), Chile.

The examined fishtails were made with highly selected rocks. At PC and PT very good quality gray, dark gray (Figure 2(b) and Figure 2(c)), and very fine black material (Figure 3(j)) was used. Many of them are respectively comparable with Georgetown flint, Onondaga, Munsungan lake and Fort Payne chert from North America. In PC, several specimens are likely limestone with small impurities and alveolus observed with magnifying glass of 10× and 20× (Figures 3(b)-(d), Figure 3(i), Figures 3(l)-(n)). Probably, some of them were affected by chemical alterations, and consequently developed clear tones on the surface (Nami, 2013: Figure 3d, 9d). Uru-

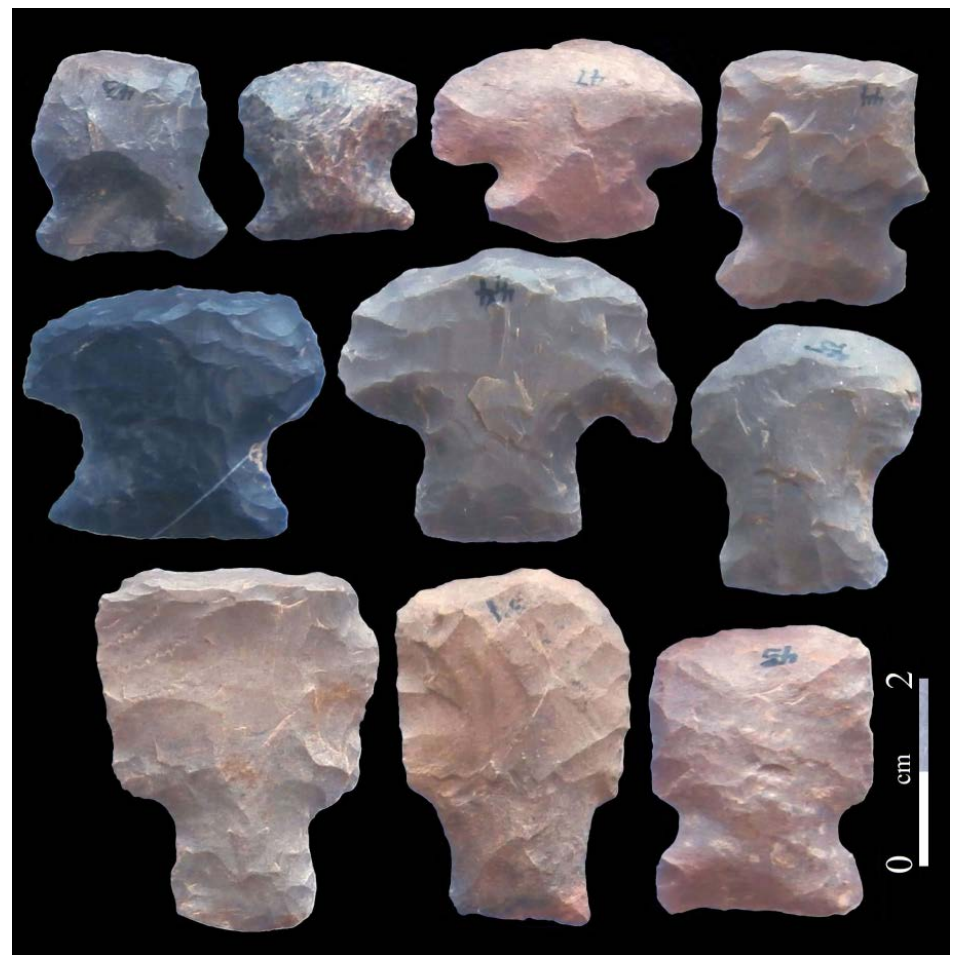

Figure 5. End-scrapers made on recycled projectile points by Holocene hunter-gatherers at PT. 


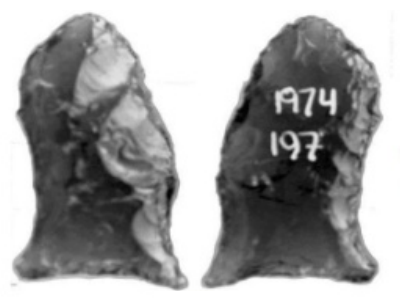

(a)

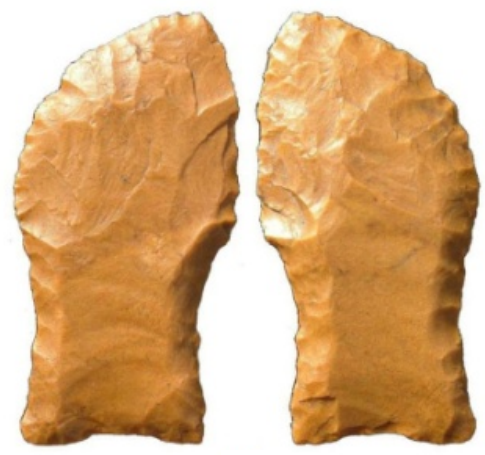

(c)
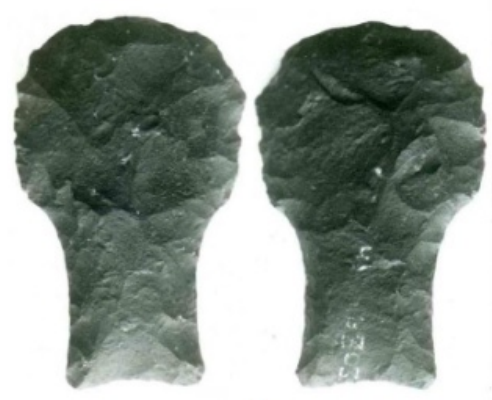

(e)
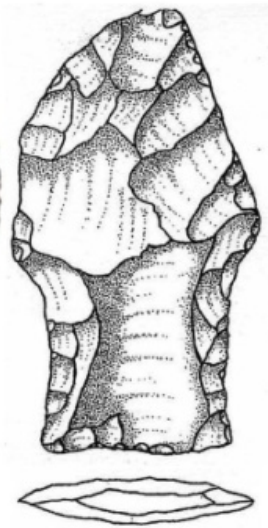
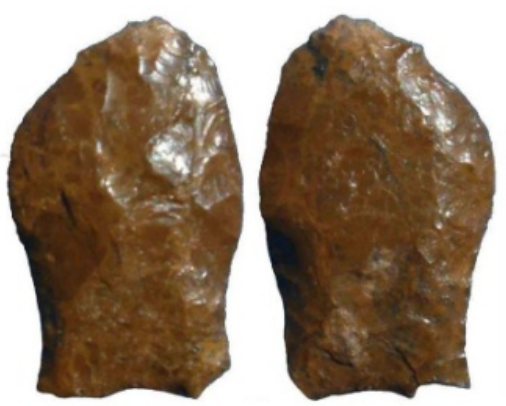

(d)

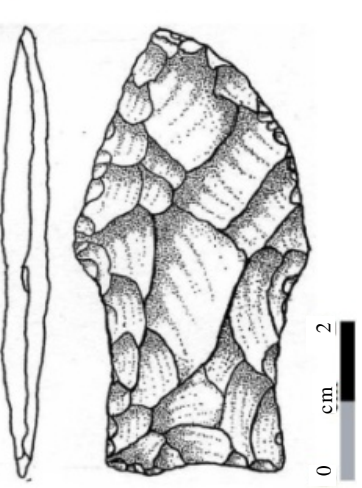

(f)

Figure 6. Reworked Fell points from different Southamerican locales. (a) Ilaló region; (b) Yi river; (c) Probably San Gregorio de Polanco; (d) Unknown origin, Uruguay; (e) Fell's cave; (f) Magallanes province (redrawn after Bahamondes and Jackson 2006).

guayan limestones have different origins (Martínez et al., 1997), and the ones with microfossils were classified as silcrete (Flegenheimer et al., 2003). Experiments using these rocks show that they have good to excellent flaking qualities and heat treatment improves some of them (Nami, 2010a). The piece depicted in Figure 2(d), probably is a heat-treated petrified wood, with available sources in CL.

Table 1 summarizes salient information concerning origin, raw materials, condition and significant data of each exemplar reported in this paper.

\section{Summary and Conclusions}

New data on Paleo-American remains from NE Uruguay allowed deepened on several archaeological topics. They added new light on the earliest lithic assemblages and stone tool behavior during the colonization of southeastern South America.

The fisthail record from CL shows strong formal variability, such as has been observed in Central and South America in general, and in the southern cone in particular (Nami, 2013, 2014b, Flegenheimer et al., 2015). Based on ethno-archaeological baselines (Politis et al., 2013), it may suggest that some morphological and dimensional differences among Fell points might reflect their employment by different age groups (i.e. kids-adults) and/or 


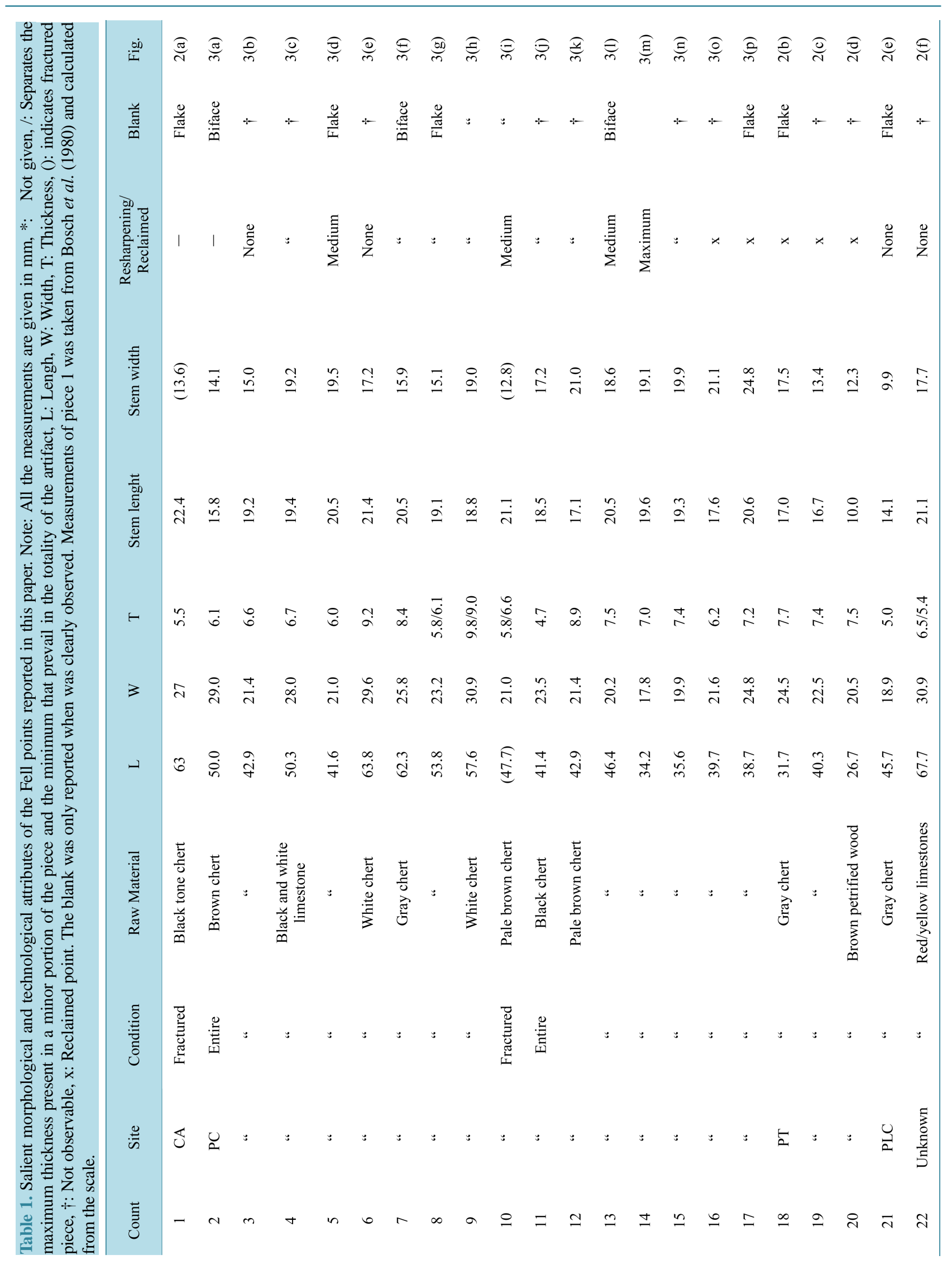


their use on different preys.

To date, along with Arroyo Cacique (Nami, 2013), PC is the surface site that has yielded the greatest number of Fell points in Uruguay. There, the lanceolate variety with incurvate stem and concave base seems to be a recurrent form. In PT and PC several Fell heads were reworked as end-scrapers and beveled pieces with concave borders. This probably constitutes a peculiar case of lithic recycling and reclaiming of fishtail points by Holocene human groups.

Like other late Pleistocene Homo sapiens hunter-gatherer lithic assemblages (Kuhn, 1992, Vaquero et al., 2012), those with fishtail points include both curated and expedient tools (sensu Binford, 1979). Fishtails were extremely curated artifacts, and occasionally recycled as knives and/or scraping tools by their makers. Ground artifacts, such as discoidals and well made bone tools (Nami, 2010b) also suggest curated strategies. Hence, an expectation of finding both expedient and curated technologies in assemblages spanning the last millennium of the Pleistocene in the southern cone is a logical conclusion.

The west of CL belongs to the Negro river basin that yielded the highest number of Fell discoveries in Uruguay (Baeza and Femenías, 1999, Nami, 2013). However, in its eastern part an interesting number of similar finds were made. Near CL, fishtails were found at Rocha department (Figure 4e, g; Figueira, 1892: figures 198-199; Bosch et al., 1980: figures 19, 21, 30; Nami, 2013: figure 24d). Moreover, similar pieces were recorded from Merin Lagoon at Treinta Tres department (Bosch et al., 1980: figure 27). In the northern border, in south Brazil points were reported from Santa Catarina and Rio Grande do Sul states (da Silva Lopes and Nami, 2011, Loponte et al., 2015).

From the technological perspective, worth to mention that as a part of the bifacial thinning process, a common fact is the presence of flake-scars with different degree of regularity over passing the symmetry axis of a biface. Sometimes, they undercut previous scars from the opposite margin (Callahan, 1979: 10, Whittaker et al., 1988, Root, 1993: figure 43g-j). However, as depicted in Figure 7, the edge-to-edge (EE) and/or overshot (O) percussion flaking in bifacial reduction is a conceptually different strategy to the usual thinning flake detaching; this is because it rapidly thin a worked piece by removing a few flakes that almost reach the opposite edge, or it is entirely eliminated (Inizan and Tixier, 1978, Bradley, 1982, Nami, 1988/1990: figure 53c, Stanford and Bradley, 2012). In this sense, remarkably, two specimens from Rocha (Figure 4(c), Figure 4(g)) display the use of EE and/or O detachments, also identified in other pieces from Baygorria dam area (Figure 4(d)), Negro river basin; La Palomita, Yi river basin; and Buena Vista hill (Figure 4(f) and Figure 4(g)). In Uruguayan Fell point manufacture it was experimentally explained by Nami (2010a), and furthermore, its use in archaeological artifacts (Nami, 2013, Nami and Castro, 2014). Like the fluting, its employment was a minority. Additionally, in other parts of South America this particular method was recognized in the Ilaló region, Ecuador (Nami, 2014b). It is important to recall that in North America EE and O percussion was a widespread Paleo-American flaking tactic (Stanford and Bradley, 2012). Also in Central and northern South America EE and O flaking was identified in preforms and thinning flakes (Cooke and Sánchez, 2003; Pearson and Ream, 2005). It is also clearly observed in finished products with expanded incurvate stems and concave bases from Ladyville, Belize (Hester et al., 1983: figure 2) and Turriabla, Costa Rica (Snarkis, 1979: figure 3b) which are comparable to examples from eastern USA. It is worth mentioning that the Uruguayan lanceolate variety with narrow blade and expanding stem resembles some fishtailed points from eastern North, Central and South America. Hence, due to morphological and technical similarities, I have suggested that South-American fishtails might have certain continuity with the fishtailed points from eastern North America (Nami, 2013). In this regard, the new data presented here support this hypothesis; probably related with second colonization wave that colonized North America as suggested by Goebel and colleagues (2008).

As seen above, Paleoindian remains from CL come from locales on fluvial courses. This fact is consistent with similar archaeological evidence in the southern cone (Nami, 2013); a circumstance that agrees with the hypothesis that fluvial environments were a significant factor in human continental colonization that, like in North America, was performed by a rapid dispersal (Anderson et al., 2013).

\section{Acknowledgements}

I am indebted to: CONICET and UBA for support my investigations, NMNH (Smithsonian Institution) for his support as associated researcher, Museo Nacional de Antropología de Uruguay for having sponsored my archaeological research; A.Toscano and A. Florines, for their constant support and help; V. H. Gannello and I. 


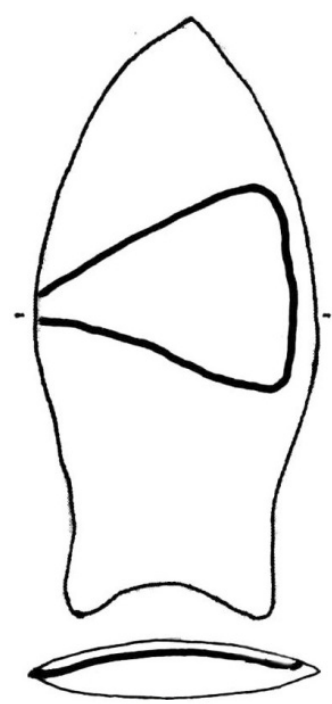

(a)

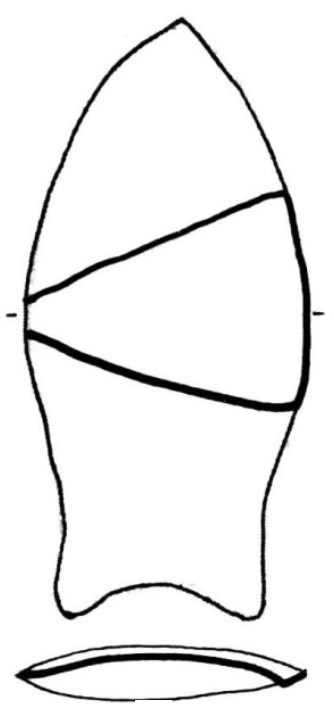

(b)

Figure 7. Schematic drawing showing the EE (a) and O (b) flaking tactic used to rapidly thin a bifacial piece.

Solimando from the MRCL for their valuable assistance in Melo. U. Meneghin kindly provided the Figure 2(a), Figures 4(a)-(c), Figure 4(e), Figure 4(f) and Figure 6(f). J. A special thanks to J. Rendo for allow me to study his collection, continuous data input, kindness and generosity. J. C. Whittaker provided useful observations, help and cooperation during the edition of this paper.

\section{References}

Adovasio, J., \& Page, J. (2002). The First Americans: In Pursuit of Archaeology’s Greatest Mystery. New York: Random House.

Akazawa, T., \& Szathmary, E. J. E. (Eds.) (1999). Prehistoric Mongoloid Dispersals. Oxford: Oxford University Press.

Amick, D. S. (1995). Patterns of Technological Variation among Folsom and Midland Projectile Points in the American Southwest. Plains Anthropologist, 40, 23-38.

Amick, D. S. (1996). Hunter-Gatherer Land Use. World Archaeology, 27, 411-426. http://dx.doi.org/10.1080/00438243.1996.9980317

Anderson, D. G., Bissett, T. G., \& Yerka, S. J. (2013). The Late Pleistocene Human Settlement of Interior North America: The Role of Physiography and Sea Level Change. In K. E. Graf, C. V. Ketron, \& M. R. Waters (Eds.), Paleoamerican Odyssey (pp. 183-203). College Station, TX: Center for the Study of the First Americans.

Baeza, J., \& Femenías, J. (1999). Nuevas observaciones sobre puntas colas de pescado. Paper presented at the 1st Conference on Pampean Archaeology, Rosario.

Baeza, J., Díaz, A., Melgar, W., Caimi, A., Etcheverry, C., Barone, J., Lucas, L., Gereda, C., Borcha A., \& Barboza, E. (1980). Informe preliminar sobre los Cerritos en la zona anegadiza de Cañada de las Pajas (Cerro Largo). III Congreso Nacional de Arqueología (1974). Anales, Montevideo: Centro de Estudios Arqueológicos.

Baeza, J., Femenías, J., Suárez, R., \& Florines, A. (2001). Investigación arqueológica en el río Negro medio (Informe preliminar). Arqueología uruguaya hacia el fin del milenio, X Congreso Nacional de Arqueología, Vol. 1, Colonia del Sacramento, 16-19 de Junio 1997, 285-295. (Montevideo: Asociación Uruguaya de Arqueología)

Bahamondes, F., \& Jackson, D. (2006). Hallazgo de una punta “Cola de Pescado” en Magallanes, Chile. Magallania, 34, 115-118. http://dx.doi.org/10.4067/S0718-22442006000200011

Binford, L. R. (1979). Organization and Formation Process: Looking at Curated Technologies. Journal of Anthropological Research, 35, 255-273.

Bird, J. (1969). A Comparison of South Chilean and Ecuatorial “Fishtail” Projectile Points. Kroeber Anthropological Society Papers, 40, 52-71.

Bonomo, M. (2012). Historia Prehispánica de Entre Ríos. Buenos Aires: Fundación de Historia Natural "Félix de Azara”.

Bosch, A., Femenías, J., \& Olivera, A. (1980). Dispersión de las puntas líticas pisciformes en el Uruguay. III Congreso 
Nacional de Arqueología. Anales. Montevideo: Centro de Estudios Arqueológicos.

Bradley, B. A. (1982). Flaked Stone Technology and Typology. In G. Frison, \& D. J. Stanford (Eds.), The Agate Basin Site (pp. 181-208). New York: Academic Press.

Bradley, B. A., Collins, M. B., \& Hemmings, A. (2010). Clovis Technology. Archaeological Series 17, Ann Arbor, MA: International Monographs in Prehistory.

Briceño Rosario, J. G. (1999). Quebrada Santa María: Las puntas cola de pescado y la antigüedad del hombre en Sudamérica. Boletín de Arqueología PUCP, 3, 19-39.

Bueno, L., Schmidt Dias, A., \& Steele, J. (2013). The Late Pleistocene/Early Holocene Archaeological Record in Brazil: A Geo-Referenced Database. Quaternary International, 301, 74-93. http://dx.doi.org/10.1016/j.quaint.2013.03.042

Cabrera Pérez, L. (2005). Patrimonio y arqueología en el Sur de Brasil y región este de Uruguay: Los Cerritos de Indios. SALDVIE, No. 5, 221-254.

Callahan, E. (1979) The Basics of Biface Knapping in the Eastern Fluted Point Tradition. A Manual for Flintknappers and Lithic Analysts. Archaeology of Eastern North America, 7, 1-180.

Callahan, E. (1981). Pamunkey Housebuilding: An Experimental Study of Late Woodland Construction Technology in the Powhatan Confederacy. Ph.D. Thesis, Washington DC: Catholic University of America.

Castiñeira, C., Cardillo, M., Charlin, J., \& Baeza, J. (2011). Análisis de morfometría geométrica en puntas Cola de Pescado del Uruguay. Latin American Antiquity, 22, 335-358. http://dx.doi.org/10.7183/1045-6635.22.3.335

Chase, A. F., Chase, D. Z., \& Topsey, H. W. (1988). Archaeology and the Ethics of Collecting. Archaeology, 41, 56-60.

Cooke, R., \& Sánchez, L. A. (2003). Panamá prehispánico: Tiempo, ecología y geografía política (Una brevísima síntesis). Istmo, 7. http://collaborations.denison.edu/istmo/n07/articulos/tiempo.html

da Silva Lopes, L., \& Nami, H. G. (2011). A New Fishtail Point Find from South Brazil. Current Research in the Pleistocene, 28, 104-107.

Dias, A. S. (2007). Da tipologia à tecnologia: Reflexões sobre das indústrias líticas da Tradição Umbu. In L. Bueno, \& A. Isnardis (Eds.), Das Pedras aos Homens: Tecnologia Lítica na Arqueologia Brasileira (pp. 33-66). Belo Horizonte: Argentum Editora.

Díaz Rodríguez, L. H. (2008). Una punta tipo “cola de pescado” con acanaladura de Quillane, Arequipa. Tambo: Boletín de Arqueología, 1, 73-82.

Dillehay, T. (2011). From Foraging to Farming in the Andes: New Perspectives on Food Production and Social Organization. Cambridge: Cambridge University Press. http://dx.doi.org/10.1017/CBO9780511793790

Femenías, J., Nami, H. G., Florines, A., \& Toscano, A. (2011). GIS Archaeological Site Record and Remarks on Paleoindian finds in the Rio Negro River Basin, Central Uruguay. Current Research in the Pleistocene, 28, 98-101.

Figueira, J. H. (1892). Los primitivos habitantes del Uruguay. In El Uruguay en la exposición histórica americana de Madrid (pp. 121-219). Montevideo: Imprenta Artística Americana de Dornaleche y Reyes.

Flegenheimer, N., Bayon, C., Valente, M., Baeza, J., \& Femenías, J. (2003). Long Distance Tool Stone Transport in the Argentine Pampas. Quaternary International, 109-110, 49-64. http://dx.doi.org/10.1016/S1040-6182(02)00202-1

Flegenheimer, N., Colombo, M., \& Pupio, A. (2009). Catálogo para Réplicas de las Primeras Ocupaciones Pampeanas. Grupo de Arqueología en las Pampas, Necochea: Municipalidad de Necochea.

Flegenheimer, N., Miotti, L., \& Mazzia, N. (2013). Rethinking Early Objects and Landscapes in the Southern Cone: FishtailPoint Concentrations in the Pampas and Northern Patagonia. In K. E. Graf, C. V. Ketron, \& M. R. Waters (Eds.), Paleoamerican Odissey (pp. 359-376). College Station, TX: Center for the Study of the First Americans.

Flegenheimer, N., Weitzel, C., \&. Mazzia, N. (2015). Miniature Points in an Exceptional Early South American Context. World Archaeology, 47, 117-136. http://dx.doi.org/10.1080/00438243.2014.991806

Gamble, C. (1996). Timewalkers: The Prehistory of Global Colonization. Cambridge, MA: Harvard University Press.

García, A. M. (2012). Sítio arqueológico do Pororó: Um Cerrito na mesoregião centro ocidental riograndense (Pinhal Grande). Master's Thesis, Rio Grande do Sul: Universidad Federal de Santa Maria.

Goebel, T., Waters, M. R., \& O’Rourke, D. H. (2008). The Late Pleistocene Dispersal of Modern Humans in the Americas. Science, 319, 1497-1502. http://dx.doi.org/10.1126/science.1153569

Graf, K. E., Ketron, C. V., \& Waters, M. R. (Eds.) (2013). Paleoamerican Odyssey. College Station: Center for the Study of the First Americans.

Hester, T. R., Steele, D. G., \& Eaton, J. D. (1983). Fluted Projectile Point from Belize, Central America. Lithic Technology, $11,29-34$.

Holmes, W. H. (1919). Handbook of Aboriginal American Antiquities. Part 1: Introductory and the Lithic Industries. Bureau 
of American Ethnology Bulletin 60, Washington DC: Smithsonian Institution.

Inizan, M. L., \& Tixier, J. (1978). Outrepassage intentionnel sur piéces bifaciales néolithiques du Qatar (Golfe arabo-persique). Quaternaria, 20, 29-40.

Iriarte, J. (2006). Landscape Transformation, Mounded Villages, and Adopted Cultigens: The Rise of Early Formative Communities in Southeastern Uruguay. World Archaeology, 38, 644-663. http://dx.doi.org/10.1080/00438240600963262

Iriarte, J., Holst, I., Marozzi, O., Listopad, C., Alonso, E., Rinderknecht, A., \& Montaña, J. (2004). Evidence for Cultivar Adoption and Emerging Complexity during the Mid-Holocene in the La Plata Basin, Uruguay. Nature, 432, 614-617.

Jennings, T. A. (2008). San Patrice: An Example of Late Paleoindian Adaptive Versatility in South-Central North America. American Antiquity, 73, 539-559.

Kuhn, S. L. (1992). On Planning and Curated Technologies in the Middle Paleolithic. Journal of Anthropological Research, 48, 185-214.

Laguens, A., Pautassi, E. A., Sario, G. M., \& Cattáneo, G. R. (2007). ELS1, A Fishtail Projectile Point Site from Central Argentina. Current Research in the Pleistocene, 24, 55-57.

Liu, H., Prugnolle, F., Manica, A., \& Balloux, F. (2006).A Geographically Explicit Genetic Model of Worldwide Human-Settlement History. The American Journal of Human Genetics, 79, 230-237. http://dx.doi.org/10.1086/505436

López Mazz, J. (2013). El poblamiento temprano del este de Uruguay. In M. Bruno (Ed.), Prehistoria de Rocha (pp. 63-84). Rocha: Comuna de Rocha/MEC.

Loponte, D., Carbonera M., \& Silvestre, R. (2015). Fishtail Projectile Points from South America: The Brazilian Record. Archaeological Discovery, 3, 85-103. http://dx.doi.org/10.4236/ad.2015.33009

Martínez, G. (2001). “Fish-Tail” Projectile Points and Megamammals: New Evidence from Paso Otero 5 (Argentina). Antiquity, 75, 523-528.

Martínez, S., Veroslavsky, G., \& Verde, M. (1997). Primer registro de Paleoceno en el Uruguay: Paleosuelos calcáreos fosilíferos en la cuenca de Santa Lucía. Revista Brasileira de Geociéncias, 27, 295-302.

Mayer-Oakes, W. (1986). El Inga. A Paleoindian Site in the Sierra of Northern Ecuador. Transactions of the American Philosophical Society, 76, 1-335.

Meltzer, D. (2009). First Peoples in a New World. Colonizing Ice Age America. Berkeley and Los Angeles, CA: University of California Press.

Meneghin, U. (2015). Secuencia crono-estratigráfica de Urupez II: Nuevas dataciones radiométricas. Origenes, 13, 1-20.

Miller, E. (1969). Resultados preliminares das escavaçōes no sítio pré-cerâmico RS-LN-1: Cerrito Dalpiaz (abrigo-sobrocha). Iheringia, 1, 43-112.

Nami, H. G. (1984). Análisis de microdesgaste de algunos artefactos líticos del sitio Casa de Piedra 1. In C. J. Gradín (Ed.), Investigaciones arqueológicas en Casa de Piedra, provincias de Buenos Aires, La Pampa y Río Negro (pp. 66-89). Buenos Aires: Dirección General de Cultura, Provincia de La Pampa, Ente Ejecutivo Presa Embalse de Casa de Piedra.

Nami, H. G. (1987). Cueva del Medio: Perspectivas arqueológicas para la Patagonia Austral. Anales del Instituto de la Patagonia, 17, 71-106.

Nami, H. G. (1988/1990). Simulación y réplica de las puntas de proyectil. In J. Fernández (Ed.), La Cueva de Haichol. Arqueología de los pinares cordilleranos del Neuquén. Anales de Arqueología y Etnología, 42/45, 227-241.

Nami, H. G. (1992). Nuevos datos en relación a las puntas de proyectil paleoindias encontradas en el Cono Sur (Neuquén, Argentina). Palimpsesto: Revista de Arqueología, 1, 71-74.

Nami, H. G. (2003). Experimentos para explorar la secuencia de reducción Fell de la Patagonia Austral. Magallania, 30, 107-138.

Nami, H. G. (2007). Research in the Middle Negro River Basin (Uruguay) and the Paleoindian Occupation of the Southern Cone. Current Anthropology, 48, 164-176. http://dx.doi.org/10.1086/510465

Nami, H. G. (2010a). Tecnología Paleoindia de Sudamérica: Nuevos experimentos y observaciones para conocer la secuencia de reducción Fell. Origenes, 9, 1-40.

Nami, H. G. (2010b). Late Pleistocene Technology in the New World: Bone Artifacts from Cueva del Medio and Other Sites in the Southern Cone of South America. In A. Legrand-Pineau, I. Sidéra, N. Buc, E. David, \& V. Scheinsohn (Eds.), Ancient and Modern Bone Artefacts from America to Russia. Cultural, Technological and Functional Signature (pp. 279286). Oxford: BAR International Series.

Nami, H. G. (2013). Archaelogy, Paleoindian Research and Lithic Technology in the Middle Negro River, Central Uruguay. Archaeological Discovery, 1, 1-22.

Nami, H. G. (2014a). Arqueología del último milenio del Pleistoceno en el Cono Sur de Sudamérica, puntas de proyectil y observaciones sobre tecnología Paleoindia en el Nuevo Mundo. In M. Farias, \& A. Lourdeau (Eds.), Peuplement et 
modalités d'occupation de l'Amérique du sud: L'apport de la technologie lithique (pp. 279-336).

Nami, H. G. (2014b). Secuencias de Reducción Bifaciales Paleoindias y Puntas Fell en el Valle del Ilaló (Ecuador): Observaciones para comprender la tecnologia lítica pleistocénica en Sudamérica. In M. Farias, \& A. Lourdeau (Eds.), Peuplement et modalités d'occupation de l'Amérique du sud: L'apport de la technologie lithique (pp. 179-220).

Nami, H. G. (2015). Paleo American Artifacts from Cerro Largo, Northeastern Uruguay. Paleo America, 1, in Press.

Nami, H. G., \& Castro, A. (2014). Fishtail Points, Technology and Microwear Analysis from the Negro River basin, Uruguay. Archaeological Discovery, 2, 65-70. http://dx.doi.org/10.4236/ad.2014.23008

Nami, H. G., \& Heusser, C. J. (2015). Cueva del Medio: A Paleoindian Site and Its Environmental Setting in Southern South America. Archaeological Discovery, 3, 62-71. http://dx.doi.org/10.4236/ad.2015.32007

Nami, H. G., Durán, V. A., Cortegoso, V., \& Giesso, M. (2015). Análisis morfológico-experimental y por fluorescencia de rayos $\mathrm{X}$ de las puntas de proyectil de obsidiana del ajuar de Uspallata Usina Sur (Mendoza, Argentina). Boletín de la Sociedad Chilena de Arqueología, in press.

Patané Aráoz, J., \& Nami, H. G. (2014). The First Paleoindian Fishtail Point Find in Salta Province, Northwestern Argentina. Archaeological Discovery, 2, 26-30. http://dx.doi.org/10.4236/ad.2014.22004

Pearson, G., \& Ream, J. (2005). Clovis on the Caribbean Coast of Venezuela. Current Research in the Pleistocene, 22, 2830.

Politis, G., González Ruibal, A., \& Hernando, A. (2013). Ethno-arqueologia do descarte de pontas de fleche entre os Awá. In A. Hernando, \& E. M. Beserra Coelho (Eds.), Estudos sobre os Awá: Caçadores-Coletores (pp. 131-154). São Luís: EDUFMA/IWGIA.

Prates, L., Politis, G., \& Steele, J. (2013). Radiocarbon Chronology of the Early Human Occupation of Argentina. Quaternary International, 301, 104-122. http://dx.doi.org/10.1016/j.quaint.2013.03.011

Rondeau, M. F. (2009). Fluted Points of the Far West. Proceedings of the Society for California Archaeology, 21, $265-274$.

Root, M. (1993). Analyses of Stone Tools and Flaking Debris. In M. Root (Ed.), Site 32DU955A: Folsom Occupation of the Knife River Flint Primary Source Area. Phase III (Part I) Archaeological Data Recovery at Lake Ilo National Wildlife Refuge, Dunn County, North Dakota: Interim Report for 1992-1993 Investigations at 32DU955A (pp. 179-227). Research Report 22, Pullman: Washington State University.

Schiffer, M. B. (1987). Formation Processes of the Archaeological Record. Albuquerque, NM: University of New Mexico Press.

Schmitz, P. I. (1987). Prehistoric Hunter and Gatherers of Brazil. Journal of World Prehistory, 1, 53-126.

Schobinger, J. (1974). Nuevos hallazgos de puntas “Cola de Pescado” y consideraciones en torno al origen y dispersión de la Cultura de Cazadores Superiores Toldense en Sudamérica. Atti del XL Congresso Internazionale degle Americanisti, 1, 33-50.

Shott, M. J. (2013). Human Colonization and Late Pleistocene Lithic Industries of the Americas. Quaternary International, 285, 150-160. http://dx.doi.org/10.1016/j.quaint.2010.12.034

Snarskis, M. J. (1979). Turrialba: A Paleo-Indian Quarry and Workshop Site in Eastern Costa Rica. American Antiquity, 44, 125-138.

Stanford, D. J., \& Bradley, B. (2012). Across the Atlantic Ice. The Origins of American's Clovis Culture. Berkeley, CA: University of California Press.

Suárez, R. (2009). Arqueología durante la transición pleistoceno-holoceno: Componentes paleoindios y movilidad de los primeros americanos en Uruguay. Doctoral Dissertation, La Plata: Universidad Nacional de La Plata.

Taddei, A. (1980). Un yacimiento de cazadores superiores en el Río Negro (Paso del Puerto) (Uruguay). III Congreso Nacional de Arqueología (1974), Anales, Montevideo: Centro de Estudios Arqueológicos.

Taddei, A. (1987). Algunos aspectos de la arqueología prehistórica de Uruguay. Estudios Atacameños, 8, 65-89.

Turner, E., \& Hester, T. (1985). A Field Guide to Stone Artifacts of Texas Indians. Houston, TX: Lone Star Books.

Vaquero, M., Alonso, S., García-Catalán, S., García-Hernández, A., Gómez de Soler, B., Rettig, D., \& Soto, M. (2012). Temporal Nature and Recycling of Upper Paleolithic Artifacts: The Burned Tools from the Molí del Salt Site (Vimbodí i Poblet, Northeastern Spain). Journal of Archaeological Science, 39, 2785-2796.

http://dx.doi.org/10.1016/j.jas.2012.04.024

White, A. A. (2013). Functional and Stylistic Variability in Paleoindian and Early Archaic Projectile Points from Midcontinental Northamerica. North American Archaeologist, 34, 71-108. http://dx.doi.org/10.2190/NA.34.1.C

Whittaker, J., Ferg, A., \& Speth, J. D. (1988). Arizona bifaces of Wyoming chert. The Kiva, 53, 321-334.

Wiessner, P. (1983). Style and Social Information in Kalahari San Projectile Points. American Antiquity, 48, $253-276$.

http://dx.doi.org/10.2307/280450 